\title{
ZPŘíSTUPŇOVÁNÍ PRAMENU゚ K DĚJINÁM UNIVERZIT PŘEDMODERNÍ DOBY VE STŘEDNÍ EVROPĚ. OHLÉDNUTÍ ZA POSLEDNÍMI DVĚMA DEKÁDAMI A VÝHLEDY DO BUDOUCNA
}

\author{
MAREK ĎURČANSKÝ - BLANKA ZILYNSKÁ
}

\section{IMPROVING ACCESSIBILITY OF SOURCES PERTAINING TO THE HISTORY OF UNIVERSITIES IN PRE-MODERN TIMES IN CENTRAL EUROPE: AN OVERVIEW OF THE PAST TWO DECADES AND OUTLOOK FOR THE FUTURE}

This contribution is a follow-up on an overview presented on the 8th congress of historians in Hradec Králové in 1999. It focuses mainly on editing activities since app. 2000 pertaining to ancient Central European universities in Prague, Vienna, Krakow, and Leipzig. This comparative approach offers an opportunity to identify the main directions of research in the history of medieval and early modern universities in the region, which were since its foundation by Charles IV dominated by the Prague university. Alongside printed editions, the authors also pay attention to improvements in accessibility which are due to digitalisation of source materials and biographic files from the university environment.

Keywords: history of education - Charles University - Prague - Krakow - Vienna - Leipzig - source editions databases of academics - historiographic overview - Middle Ages and Early Modern Period - pre-modern era

DOI: $10.14712 / 23365730.2019 .2$

Naše malé ohlédnutí má svůj výchozí bod v bilančním př́íspěvku na 8. sjezdu historiků v Hradci Králové v roce 1999, který shrnul stav pramenů k dějinám vzdělanosti a jejich dostupnost. ${ }^{1}$ Svoji pozornost tentokrát zaměříme především na ediční činnost od roku cca 2000, týkající se starobylých univerzit střední Evropy - v Praze, Vídni, Krakově a Lipsku.

Předešlá bilance se opírala o právě zakončené publikování čtyřsvazkových dějin UK, ${ }^{2}$ které sice představovaly syntézu dosavadního bádání, byly však vydány v reprezentačním formátu a bez poznámkového aparátu, proto slouží jako badatelské východisko jen v omezené míře. Vyslovená obava, aby se nestaly spíše balvanem na cestě než orientačním mezníkem, se tak skoro naplnila. ${ }^{3}$ Jsme na cestě k novým stručným dějinám pražské univerzity, a tak je na místě ohlédnout se po nových badatelských trendech a edicích.

1 Blanka ZılynsKÁ, Prameny a pomůcky ke studiu dějin vzdělanosti. Bilance a desiderata, Práce z Archivu Akademie věd 7, 2002, s. 23-35.

2 František KaVka - Josef Petráň (edd.), Dějiny Univerzity Karlovy 1348-1990, I-IV, Praha 1995-1998.

3 B. ZiLYNSKÁ, Prameny a pomůcky, str. 26. 
Pražská univerzita byla v minulosti postižena těžkými ztrátami důležitých tradičních pramenů. Na rozdíl od většiny starobylých univerzit postrádá především matriky. Přesto stav edičního zpř́ístupnění zbytků jejích nejstarších dokumentů neodpovídá této situaci. Informace ze základních pramenů $\mathrm{k}$ dějinám pražské univerzity ve středověku a raném novověku, jakými jsou především děkanská kniha, listiny a statuta, se stále čerpají z edic 200 let starých, ${ }^{4}$ jen v málo př́padech jsou k dispozici vydání mladší. ${ }^{5} \mathrm{Na}$ tom se zatím nic nezměnilo ani po roce 2000. Také mezi životopisné a bibliografické příručky od doby minulého bilancování skoro nic nepřibylo. ${ }^{6}$ Kudy se tedy ubíralo ediční a badatelské úsilí.

Jako nový trend můžeme bezpochyby označit cesty, které nabízí všude pronikající elektronizace. Usnadňuje editorskou činnost, umožňuje šíření editovaných textů, nabízí databáze různého zaměření a poskytuje evidenční a orientační pomůcky. Pražský univerzitní archiv začal využívat těchto možností, dá se říci, nedávno. Nejobjemnější podniky se týkají 19. a 20. století a pojedná o nich samostatný referát. ${ }^{7}$ Co se týče staršího období dějin, je možno připomenout zapojení AUK do rakouského mezinárodního projektu MONASTERIUM, kde byl prezentován listinný fond. Tato databáze obsahuje jen základní údaje o univerzitních listinách. ${ }^{8}$ Kvalitnější digitalizace a detailní odborný popis poskytuje univerzitní repozitár obsahující jak většinu listin, ${ }^{9}$ tak některé úřední rukopisy. ${ }^{10}$

Literární kodexy, spojené svým původem s univerzitou, obsahuje jiná databáze digitalizovaných rukopisů - MANUSCRIPTORIUM. ${ }^{11}$ Její provoz a hlavně zpř́istupněný materiál nevychází z fondů univerzitního archivu. Kodexy s díly univerzitních mistrů se dostaly

4 Monumenta historica Universitatis Carolo-Ferdinandeae Pragensis, I/1,2, II/1, Pragae 1830-1834; Monumenta historica Universitatis Pragensis, III, Statuta, Pragae 1848.

5 Karel KuČERA - Miroslav Truc (edd.), Matricula facultatis medicae Universitatis Pragensis 1657-1783, v obnovené ediční řadě: Monumenta Historica Universitatis Carolinae Pragensis, I, 1968; M. TRUC (ed.), Album Academiae Pragensis Societatis Jesu 1573-1617 (1565-1624), MHUCP II, 1968.

6 Bibliografie univerzitik dále tiskem vydávána není. Biografické slovníky pro starší dějiny také nepřibyly, jen seznam mediků pro celé stř̌edověké období byl reprintován: František ŠMAHEL, Die Prager Universität im Mittelalter. Gesammelte Aufsätze / The Charles University in the Middle Ages. Selected Studies, Leiden - Boston 2007, s. 134-158, jako prosopografická příloha studie o lékařské fakultě. Mnohé úzké vazby s univerzitou měla také činnost veřejných notářů, jejichž značně rozšířený soupis byl publikován v rámci knihy: Josef NuHLíČEK - Ivan HLAVÁČEK - Markéta MARKOVÁ, Veřejní notářri v českých městech, zvláště v městech pražských až do husitské revoluce, Praha 2011 (srv. recenzi in AUC-HUCP 52/1, 2012, s. 113-116). V tisku je biografický slovník pro období II. sv. války: Michal ŠIMŮNEK - Antonín KostLÁN, Zmizelé elity: Vědci a akademici z českých zemi jako oběti nacistické perzekuce, 1939-1945 (biografický slovník), sv. I (A-K); vyšel další svazek slovníku lékařů: Karel ČERnÝ - Ludmila HlavÁČKOvÁ (edd.) a kol., Biografický slovník 1. lékařské fakulty Univerzity Karlovy 1945-2008, I, A-L, Praha 2018. Nově zahájený grant HÚ AV ČR ve spolupráci s ÚDAUK (Universitas magistrorum. Profesoři pražské utrakvistické univerzity 1458-1622, GAČR, č. 18-00408S) dává naději na vydání encyklopedie mistrů pražské univerzity pro období 1449-1622.

7 Digitalizované matriky a další knihy z fondů AUK jsou dostupné z: https://is.cuni.cz/webapps/archiv < ověřeno 9. 9. 2017> Srv. také Petr CAJTHAML - Lenka VAŠKovÁ, Studenti pražských univerzit 1882-1945. Digitalizace $v$ Archivu Univerzity Karlovy, Archivum Trebonense 14, 2017, s. 204-215. Proklik na digitalizované staré edice i digitalizační projekt novodobých matrik obsahuje stránka genealogické společnosti: http://genwiki. genealogy.net/Universit\%C3\%A4tsmatrikel\#Prag_.28Karls-Universit.C3.A4t.29 < ověřeno 1. 9. 2018>.

8 Monasterium je dostupné $\mathrm{z}$ : http://www.mom-ca.uni-koeln.de/mom/CZ-UKP/archive? lang=deu\&lang=ces <ověřeno 9. 9. 2017>; chybí signatury II/1 až II/48.

9 Srv. Michal Svatoš, Digitalizace listin Archivu Univerzity Karlovy v Praze (Bilance jednoho projektu), AUC-HUCP 49/1, 2009, s. 113-117.

10 Univerzitní repozitáŕ dostupný z: http://digitool.is.cuni.cz/R/NU842GBTFG7DV1JS1R43BM5JMI1TSPSPFVR3JXXYTEV3 NE3RLL-01491? func $=$ collections\&collection id=2133\&pds handle $=$ GUEST $<$ ověřeno 9. 9. 2017>; v repozitáři se aktuálně nachází 244 listin, 5 úředních rukopisů řady A, 2 matriky z let $1572-1615$.

11 Manuscriptotium je dostupné z: http://www.manuscriptorium.com/apps/index.php\#search <ověřeno 1. 9. 2018>. 
již v závěru 18. století mimo př́mý dosah univerzitních činitelů při vytvoření samostatné, veřejnosti otevřené univerzitní, resp. Královské, či Státní nebo Národní knihovny. ${ }^{12}$ Písemný materiál s univerzitou spojený (a byly to třeba i disertační práce) se tak roztrhl mezi dvě samostatné instituce. A dodejme, že podobný osud, ale podmíněný jinými okolnostmi, potkal i listiny, z nichž část se ocitla např. $v$ archivu Národního muzea. ${ }^{13}$

Další možností využití nových technologií je elektronická evidence studentů. Pro české země a jejich starší dějiny takový projekt zahájen nebyl. ${ }^{14}$ Pro oblast někdejší Svaté ř́še římské však vzniká monumentální databáze Repertorium Academicum Germanicum (RAG), do níž jsou pro období do poloviny 16. století rozepisovány dochované matriky říšských universit německé jazykové oblasti (celkem $18 \mathrm{v}$ této době reálně činných univerzit) - včetně pražské. ${ }^{15}$ Ta však mohla být zahrnuta jen omezeně, protože nemá své středověké a raněnovověké matriky (proto není zahrnuta do dalších plošných výzkumů, např. $R$. Schwingese ${ }^{16}$ ). Německé kolegy následovali také Poláci (o krakovském projektu se ještě zmíníme) a Mad’aři, kteří mapují formou neveřejné databáze a knižně vydávaných svazků své studenty na evropských univerzitách. ${ }^{17}$

Jen pro úplnost můžeme zmínit, že digitalizačních a elektronických možností využívá AUK také k informování o svých fondech a zpř́ístupnění inventářr jednotlivých fondů. ${ }^{18}$

$* * *$

Přecházíme ke klasické formě zpř́ístupňování pramenů v tištěné podobě. Pro období středověké univerzity vykonal jak celkově, tak v poslední době největší díl práce bez pochyby Fr. Šmahel. Nebudeme vypočítávat všechny jeho dílčí edice časopisecké, ${ }^{19}$ připomenout ale

12 Marie PavlíkovÁ, Vznik a vývoj univerzitní knihovny, in: Ivana Čornejová (ed.), Dějiny Univerzity Karlovy, II, 1622-1802, Praha 1996, s. 203-223; Karel СнувА, Zveřejnění nové Karolinské knihovny, Ročenka Universitní knihovny 1957, Praha 1958, s. 5-47; Josef Petráñ, Památky knižni kultury, in: týž (ed.), Památky Univerzity Karlovy, Praha 1999, s. 172-206.

13 K tomu Michal Svatoš, Rozsah a původni podoba listinného fondu pražské univerzity, AUC-HUCP 25/2, 1985, s. 15-33; TÝž, Diplomatický rozbor listin k dějinám pražské univerzity, ib. 29/2, 1989, s. 71-95.

$14 \mathrm{~K}$ digitalizaci matrik novodobých viz pozn. 7.

15 K databázi RAG a výsledkủm projektu obecně srovnej Rainer C. SCHwingEs, Universitätsbesuch im Reich vom 14. zum 16. Jahrhundert: Wachstum und Konjunkturen, in: R. C. Schwinges, Studenten und Gelehrte. Studien zur Sozial- und Kulturgeschichte, Leiden - Boston 2008, s. 87-118; aktuálně Christian Hesse, Das Wirken der Gelehrten in der Gesellschaft. Möglichkeiten und Perspektiven des Repertorium Germanicum Academicum $(R A G)$, in: Krzysztof Ożóg - Maciej Zdanek (Hgg.), Universitätsstudium und Gesellschaft in Mitteleuropa vom 15. bis zum 18. Jahrhundert, Kraków 2017, s. 253-264. Databáze dostupná z: http://www.rag-online.org/en/ component/content/article/109.html < ověřeno 9. 9. 2017>. Rozepsáni jsou tam i pražští graduovaní, doložení v Liber decanorum (MUP I/1,2) do r. 1450, a údaje o osobách pojednaných v odborné literatuře.

16 Rainer Christoph Schwinges, Deutsche Universitätsbesucher im 14. und 15. Jahrhundert: Studien zur Sozialgeschichte des Alten Reiches, Stuttgart 1986 (Beitrage zur Sozial- und Verfassungsgeschichte des Alten Reiches), i když k pražským univerzitním pramenům přihlížel (MUP I-III).

17 Webová aplikace mad’arského projektu nebyla dosud zpř́stupněna, knižní publikace vycházející mad’arsky citují P. CAJTHAML - L. VašKovÁ, Studenti pražských univerzit, s. 207, pozn. 12.

18 Viz web UDAUK: https://www.udauk.cuni.cz/ARCH-33.html < ověřeno 1. 9. 2018>.

19 František ŠMAhEL, Die Verschriftlichung der Quodlibet-Disputationen an der Prager Artistenfakultät bis 1420, in: Fritz Peter Knapp - Jürgen Miethke - Manuela Niesner (edd.), Schriften im Umkreis mitteleuropäischer Universitäten um 1400, Leiden 2004, s. 63-91 (s katalogem pražských kvodlibetů a seznamem kvestií kvodlibetu Jindřicha z Rybenice, asi 1394), přetisk in: týž, Die Prager Universität, s. 359-386; Týž, Zwei Vorlesungsverzeichnisse zum Magisterium an der Prager Artistenfakultät aus deren Blütezeit (1388-1390), Jahrbuch für Universitätsgeschichte 4, 2001, s. 195-207 (s edicí), přetisk in: týž, Die Prager Universität, s. 316-335; TY̛ž, Doplňky k dějinám mistrovských koleji pražské univerzity do roku 1420, AUC-HUCP 33-34/1-2, 19931994 (2007), s. 13-43 (se seznamem kolegiátů Karolina); Týž, Zatoulané drobné texty v nejstarších kolejních 
musíme knižní vydání katalogů kolejních knihoven ${ }^{20}$ a díla Jeronýma Pražského. ${ }^{21} \mathrm{Z}$ jeho iniciativy také bylo zahájeno vydávání volné ediční řady univerzitních pramenů - Documenta historica Universitatis Carolinae Pragensis (DUP). Jako první svazek byla publikována edice nejstarších univerzitních statut. Př́ípravná studie $\mathrm{k}$ ní se objevila už v jeho nejnovějším výboru univerzitních statí z r. $2016 .{ }^{22} \mathrm{~V}$ dalších letech se pak počítá s vydáním matriky právnické fakulty ze 17 . století a dvou svazků akt pražské univerzity z druhého desetiletí téhož století. ${ }^{23}$

Mimořádnou situaci vytvořil neobvyklý nález: na antikvářském trhu se objevily dvě listiny související se založením pražské Karoliny. Jedná se o druhý exemplář buly papeže Klimenta VI. z 26. ledna 1347 a její notářsky ověřený opis. Obě listiny byly univerzitou zakoupeny a uloženy v Archivu UK. Po tomto epochálním nálezu bylo třeba představit př́růstek veřejnosti a vysvětlit jeho význam. Proto byla vydána informační publikace s edicí obou listin, překladem a fotoreprodukcemi. ${ }^{24}$ Výhledově lze očekávat i zásadnější studie. ${ }^{25}$ Pražská univerzita tak má nečekaně $\mathrm{k}$ dispozici nové vydání jednoho ze svých konstitutivních dokumentů, celkově se však zájem o ně dosud projevoval spíše jen studiemi a úvahami. ${ }^{26}$

Na úředním materiálu více práce vykonáno nebylo, ačkoli manuál děkana artistické fakulty př́ímo volá po novém zpracování. Ostatní ediční počiny jsou totiž vesměs věnovány jednotlivým osobnostem s univerzitou svázaným. Zcela mimořádný př́pad představuje Jan Hus a projekt jeho sebraných spisů: od roku 2000 se objevilo 7 svazků husovských - novinky

katalozích, AUC-HUCP 50/2, 2010, s. 98-114 (s edicí); TÝž, Drobné záhady rejstřiku Rečkovy koleje, AUC-HUCP 53/2, 2013, s. 11-21 (s edicí).

20 Zuzana Silagiová - František Šmahel (edd.), Catalogi librorum vetustissimi Universitatis Pragensis / Die ältesten Bücherkataloge der Prager Universität (Corpus Christianorum - Continuatio Mediaevalis 271: Magistri Iohannis Hus Opera omnia..., tomus XXXVIIB - Supplementum 2), Turnhout 2015. Recenze v AUC-HUCP 56/2, 2016, s. 137-139.

21 František Šmahel - Gabriel Silagi (ed.), Magistri Hieronymi de Praga Quaestiones, polemica, epistulae, Turnhout 2010. V české verzi monografie je připojen pouze komentovaný soupis Jeronýmova díla, viz: František Šmahel, Život a dílo Jeronýma Pražského. Zpráva o výzkumu, Praha 2010, s. 239-337.

22 První svazek nové řady: František ŠMAHeL - Gabriel Silagi (edd.), Statuta et acta rectorum Universitatis Carolinae Pragensis (1360-1614), Praha 2018 (Documenta Historica Universitatis Carolinae Pragensis 1). Srv. F. Šmahel, Nejstarši statuta pražské univerzity. Prolegomena k jejich edici, in: týž, Alma mater Pragensis: studie k počátkům Univerzity Karlovy, Praha 2016, s. 43-61.

23 Zahrnuty budou prameny úřední provenience nebo bezprostředně spjaté s univerzitou. Texty osobního charakteru (korespondence, paměti apod.) budou vydávány mimo tuto ediční řadu. Plánovány jsou svazky: Marek D̆URČANSKÝ - Marek BrČÁK - Lenka VAšKovÁ, M 6 - Matricula facultatis juridicae ab unione usque ad a. 1685; Marek ĎurČAnsKÝ - Bohdana DivišovÁ, A 14a, A14 b - Acta Universitatis Pragensis 1616-1619, 1619-1622.

24 Jan Royt (ed.), Nejstarši listiny Univerzity Karlovy, Praha 2018 (autorsky se podíleli: Tomáš Zima, Ivan Hlaváček, Blanka Zilynská, Jan Royt a Petr Svobodný).

25 Osudy zakládacích listin studuje Jan Hrdina.

26 Fulvio Delle Donne, The Charters of Foundation of Prague and Naples: the Models and their Reuse, AUC-HUCP 55/1, 2015, s. 97-108; František ŠMAHEL, Alma mater Pragensis. Studie k počátkům Univerzity Karlovy, Praha 2016, zvl. s. 13-42; v německé verzi TÝž, Die Anfänge der Prager Universität. Kritische Reflexionen zum Jubiläum eines „,Nationalen Monuments “, in: týž, Die Prager Universität im Mittelalter, s. 3-50; Michal Svatoš, in: Dějiny Univerzity Karlovy, I, 1347/48 - 1622, Praha 1995, s. 32-37. Drobnou výjimku představuje vydání nejstarších statut pražské univerzity: Michal Svatoš, Ordinationes Arnesti. Il primo statuto universitario praghese e il ruolo di Ernesto di Pardubice alla nascità dell'università, in: Roma - Praga / Praha - Ř́m. Omaggio a Zdeňka Hledíková, a cura di Kateřina Bobková-Valentová - Eva Doležalová - Eva Chodějovská Zdeněk Hojda - Martin Svatoš, Praga 2009, s. 99-106, s edicí na s. 105-106. 
i reprinty - a navíc dva svazky nehusovských univerzitik v rámci Opera omnia. ${ }^{27}$ Mimo řadu Opera omnia vyšlo z Husových děl málo, jsou to z pochopitelného důvodu především popularizační př̀eklady: pro české publikum univerzitní projevy a oblíbené dopisy, ${ }^{28}$ pro německé prostředí je určen rozsáhlý výbor z díla zpracovaný mj. T. Krzenckem. ${ }^{29}$ Obsahuje výběr 37 textů z let 1403-1415 v novém německém překladu, vč. prvního úplného německého překladu spisu De ecclesia. Pro specialisty je určeno pečlivé vydání překladu části Husova De ecclesia iniciovaného před r. 1548 zřejmě Martinem Bucerem, doprovázené v Kotowského publikaci fotografickou faksimilí původního rukopisu. ${ }^{30}$

Další osobnosti nemůžeme vypočítávat jmenovitě a v úplnosti, připomeneme proto jen některé. Zájem byl věnován mistrům starší generace, německého původu, kteří založili věhlas pražské univerzity, ale posléze přešli na jiné školy. Vydána byla napřr. díla mistrů Jindřicha Tottinga z Oyty, na jehož ,školu“ se vůbec obrací v poslední době zvýšená pozornost, ${ }^{31}$ nebo Matouše z Krakova a dalších. ${ }^{32}$

Velká pozornost je věnována mistrům, kteří přešli z Prahy do Krakova. Jmenujme alespoň Stanislava ze Skalbimierza, ${ }^{33}$ Jindřicha Bitterfelda z Brzegu ${ }^{34}$ a Jana ze Ząbkowic alias

27 Ze sedmi svazků jsou čtyři novými edičními počiny Husových Opera omnia (J. Kejř - Questiones, J. Nechutová a kol. - Enarratio Psalmorum, dva svazky dubií J. Zachová), tři svazky reedicí (B. Ryba - G. Silagi, Quodlibet a Postilla adumbrata; J. Eršil, Polemica). Dva svazky nejsou Husovy - dílo Jeronýma pražského (viz pozn. 21) a kolejní knihovny (viz pozn. 20) - editor F. Šmahel za spolupráce Z. Silagiové, resp. G. Silagiho). Plné citace viz Pavel SoukuP, Jan Hus. Život a smrt kazatele, Praha 2015, s. 198; nověji Bohumil RYBA - Gabriel Silagi (edd.), Magistri Iohannis Hus Postilla adumbrata, Turnhout 2015 (Corpus Christianorum, Continuatio Mediaevalis 261; Mag. Joh. Hus Opera omnia XIII). Srv. Blanka ZiLYNskÁ, Literárni sklizeň husovského jubilejního roku 2015, AUC-HUCP 55/2, 2015, s. 133-145.

28 Jana Nechutoví - Jana Fuksová (edd.), Mistr Jan Hus v polemice a za katedrou, Brno 2015. Další popularizační: František ŠmaHEL, Hranice pravdy. Husovy listy z Kostnice podle edice Bohumila Ryby, (reedice) Argo, Praha 2015; Jan Hus, Listy z Kostnice, Praha 2015; Martin Wernisch (ed.), Mistr Jan Hus: Knihy kacírú se mají čist, Praha 2015.

29 Armin Kohnle - Thomas Krzenck (Hgg.), unter Mitarbeit von Friedmann Richter und Christiane Domtera-SchleichardT, Johannes Hus deutsch, Leipzig 2017. Recenze v AUC-HUCP 58/2, zde ve svazku.

30 Norbert Kotowsкi (Hg.), Jan Hus: De ecclesia. Von der Kirchen Gottes. Die älteste deutsche Übersetzung von de ecclesia in Straßburg (viertes Kapitel), spiritus rector: Martin Bucer, Stadtarchiv Straßburg, Flacius-Verlag-Fürth/Gräfenberg 2015.

31 Harald Berger (ed.), Heinrich /Totting von Oyta/: Schriften zur Ars vetus. Textedition, München 2015; Jindřichově osobě se věnoval např. Jan ODstrčı́í v rámci grantového projektu GA UK, čís. 1124413, nazvaného Prague Teacher Henricus Totting de Oyta in the Medieval Bohemical Manuscripts from Corpus Christi Library in Cambridge: An Analysis and an Edition of Selected Parts of his Works, realizovaného na FF UK v Praze. Srv. pozn. 44, kde citován jeden z výstupů grantu.

32 Matthias Nuding, Matthäus von Krakau: Theologe, Politiker, Kirchenreformer in Krakau, Prag und Heidelberg zur Zeit des Großen Abendländischen Schismas, Tübingen 2007 (s edicemi drobnějších textů diplomatického charakteru); TÝž (ed.), De contractibus, Heidelberg 2000; Wladyslaw SEŃKo (ed.), Mateusz z Krakowa, O praktykach Kurii Rzymskiej, Kęty 2007; Drahomíra BreEdveld-BARÁnKovÁ, Matthaeus de Cracovia: Tractatus Birgittini = Brigitské traktáty, Praha 2008; Helmut BeIFuss, Matthäus von Krakau: ein Vorreformator und die deutschsprachigen Bearbeitungen seines Eucharistietraktates: Edition und geistesgeschichtliche Einordnung, Hamburg 2012. Přehled nejnovější literatury včetně zahraniční i edičních podniků podal Michael LužNÝ, Matouš z Krakova. Působení v Praze a rukopisy jeho děl v českém prostředí, bakalářská práce ÚČD FF UK, Praha 2017.

33 Zofia WŁoDEK, Z dziejów filozofii i teologii na Uniwersytecie Krakowskim w XV wieku: sylwetki, teksty, studia, Kraków 2011 (Historia et monumenta universitatis Jagellonicae II) - výbor studií autorky, zahrnuje i drobné edice, např. Stanisława ze Skalbimierza a Jana Falkenberga. TÁž, Stanislas de Skalbmierz, un court traité contre les hussites sur la vision spirituelle. Introduction et texte, in: Paul J. J. M. Bakker (ed.), Chemins de la pensée médiévale. Etudes offertes à Zénon Kaluza, Turnhout 2002, s. 493-512.

34 Pavel ČERnuŠKa (ed.), Jindřich z Bitterfeldu. Eucharistické texty, Brno 2006; Bruno Mazur - Wladysław SEŃKO - Richard TATARZYŃSKi (edd.), Henricus Bitterfeld de Brega OP, Tractatus de vita contemplativa et aktiva, Warszawa 2003. 
z Frankensteinu, ${ }^{35}$ jejichž literární činností a jejím zpřístupňováním se zabývají především polští kolegové.

Také mistři působící dlouhodobě v Praze se dočkali publikování svých děl - jedná se o osobnosti např́íc generacemi. Pozornost upoutal např. Mikuláš Biceps, ${ }^{36}$ Šimon z Rokycan, ${ }^{37}$ Petr z Uničova, ${ }^{38}$ Štěpán Páleč, ${ }^{39}$ Mařík Rvačka, ${ }^{40}$ Jakoubek ze Stříbra, ${ }^{41}$ Křištan z Prachatic, ${ }^{42}$ Jan Jeroným z Prahy ${ }^{43}$ a další.

Zájem o pražskou univerzitu a její duchovní milieu stoupá, jak dokazují i konferenční aktivity především zahraničních badatelů. ${ }^{44}$

Vedle odborných edic můžeme zmínit i popularizační, resp. výukové antologie. ${ }^{45}$

Shrnout lze v tom smyslu, že hlavní badatelský zájem se v uplynulém dvacetiletí soustřed’uje na literární činnost pražských mistrů a zpř́stupňovány jsou jejich texty. Zájem je zaměřen na několik okruhů - skupinu nominalistů konce 14. stol., na počátky recepce Wyclifa, pražské absolventy působící v Krakově, Husa a jeho stoupence i odpůrce.

Na druhé straně se výrazně nepokročilo ve zpracování institucionálních dokumentů s jednou, ale velmi důležitou výjimkou univerzitních statut. To by mohl podpořit právě započatý projekt ediční ŕady, o němž jsme se již zmínili.

$$
* * *
$$

35 Anna Zajchowska, Między uniwersytetem a zakonem. Biografia i spuścizna pisarska dominikanina Jana z Ząbkowic († 1446), Warszawa 2013 (se soupisem díla a knihovny).

36 Włodzimierz ZEGa, Filozofia Boga w Quaestiones Sententiarum Mikolaja Bicepsa. Krytyka prądów nominalistycznych na Uniwersytecie Praskim w latach osiemdziesiatych XIV wieku, Warszawa - Bydgoszcz 2002.

37 Milada Svobodová, Dochované kodexy z knihovny M. Šimona z Rokycan, in: Jitka Radimská (ed.), K výzkumu zámeckých, měšt’anských a církevních knihoven. Čtenár̆ a jeho knihovna. = Pour une étude des bibliothèques aristocratiques, bourgeoises et conventuelles (Opera romanica 4), České Budějovice 2003, s. 13-30.

38 Václav BoK - Freimut Löser, Der Widerruf des Peter von Uničov vor der Prager Universitätsgemeinde (1417), in: F. P. Knapp - J. Miethke - M. Nieser (edd.), Schriften im Umkreis mitteleuropäischer Universitäten um 1400, Leiden - Boston 2004, s. 231-250 (tamtéž další studie k mistrům působícím i v Praze).

39 Ivan Müller (ed.), Commentarius in De universalibus Iohannis Wyclif Stephano de Palecz ascriptus, Praha 2009.

40 Zdeněk UhLír, Determinace Mařika Rvačky na obranu Řehoře XII., AUC-HUCP 41, 2001, $177-193$.

41 Romolo Cegna (ed.), Iacobelli de Misa Sermo in festo Corporis Christi, in: Týž, Nicolai (ut dicunt) de Dresda vulgo appellati de Čeruc ... Puncta, Varsovie 1996, s. 188-197; TÝž, Magistri Jacobelli De iuramento, in: Helena Krmíčková - Anna Pumprová - Dana Růžičková - Libor Švanda (eds.), Querite primum regnum Dei (Sb. Jany Nechutové), Brno 2006, s. 561-566; Mirek ČEJKA - Helena KRMíčKovÁ (edd.), Dvě staročeská utrakvistická díla Jakoubka ze Stř́bra, Brno 2009 (Opera Universitatis Masarykianae Brunensis, Facultas Philosophica, Nr. 379); Helena KRmíčKovÁ, Articulus pro communione sub utraque specie Jakoubka ze Stř́bra, Studie o rukopisech 39, 2009, s. 73-87, edice na s. 84-87.

42 Zuzana Silagiová (ed.), Kř́ištan z Prachatic. Základy aritmetiky - Algorismus prosaycus, Praha 1999; Hana Florianová-MišKovské, Křšš́an z Prachatic. O pouštění krve-De sanguinis minucione, Praha 1999; Alena Hadravová - Petr Hadrava (eds.), Kř̌̌śáa z Prachatic. Stavba a užití astrolábu, Praha 2001.

43 Jan STEJSKal, Podivuhodný př́běh Jana Jeronýma, Praha 2004, se seznamem děl a jejich dochováním (s. 85-89); moderní edice chybí.

44 Jan OdstrČIlík - Francesca Battista - Riccardo Burgazzi, (eds.), The First Decades of Prague University: Transforming Intellectual Space in 14th century Central Europe, AUC-HUCP 55/1, 2015 - svazek obsahuje příspěvky z mezinárodní konference mladých badatelů, konané 2014 v Praze a věnované mj. Jindřichu Tottingovi z Oyty, Konrádovi z Ebrachu a Janovi z Mýta. Srv. dále Martin DeKarLi, rec. ad: Before and After Wyclif: Sources and Textual Influences (Università degli Studi di Milano), AUC-HUCP 56/2, 2016, s. 121-129; TÝž, ref. o konferenci konané ve Skotsku v květnu 2017, University of St Andrews, věnované pozdně středověké logice s velkým zastoupení pražských textů, AUC-HUCP 57/2, 2017, s. 152-155.

45 Jako př́klad uvedeme: Lucie DolEžAlová - Michal Dragoun - Jan CTIBOR (edd.), Čitanka latinských textů z pozdně středověkých Čech, Praha 2017, kde figuruje univerzita ukázkami z tvorby Jana Husa, z příručky kvodlibetáře Prokopa z Kladrub a jiných odborných textů i z didaktického traktátu o tom, jak se má studovat. Sem patří i výbor překladů citovaný v pozn. 28. 
Pramenů úřední povahy se vztahem k pražské univerzitě z období raného novověku bylo v posledním čtvrtstoletí ve formě kritických edic vydáno jen málo; ty nejvýznamnější jsou takřka všechny dílem Karla Beránka († 9. 12. 2015). Oproti svým starším edičním počinům, zahrnujícím především materiál 16. století, se soustředil hlavně na rukopisy z období jezuitské univerzity mezi Bílou horou a univerzitní unií. ${ }^{46}$ Úředním rukopisům předbělohorského období se nejpodrobněji věnovali Mlada Holá a Martin Holý, zejména účtům koleje Českého národa z let 1541-1611.47

Zajímavou a ne zcela typickou záležitostí jsou dvě bibliofilská vydání starých tisků (ovšem s překladem z latiny a př́islušným edičním aparátem) - to je možná cesta, jak oslovit také širší vzdělanou veřejnost. Jedná se o relativně známou publikaci s nejstarším vyobrazením Karolina vydanou k poctě lékaře Ignáce Schamského (1687-1715) v souvislosti s jeho promocí a o století starší zprávu o veřejné pitvě realizované pozdějším rektorem utrakvistické univerzity Janem Jesseniem. ${ }^{48} \mathrm{Z}$ raně novověkých osobností pražské univerzity je to právě Jessenius, kdo poutá asi největší pozornost českých a slovenských badatelů; výbor z jeho díla je nově zpřístupněn také v monografii Tomáše Nejeschleby. ${ }^{49}$ Objevují se ale také další edice spisů renesančních a barokních učenců spojených s pražskou univerzitou, ${ }^{50}$ př́ípadně dobových biografických textů k jejich životu (což platí zvláště pro elogia $)^{51}$. Z pramenů narativní povahy je pro období raného novověku jednoznačně nejvýznačnějším počinem edice pamětí lékaře Jana Theobalda Helda, vydaná Danielou Tinkovou. ${ }^{52}$

Svým životem žije také Rukovět' humanistického básnictví, která se od svých prvních svazků v 60. letech stala trvalou inspirací a pobídkou pro prosopografický výzkum. ${ }^{53}$ Nedošlo sice na vydání rejstříků, jež by práci s ní výrazně ulehčily, k dispozici jsou ale věcné dodatky. 54

46 Karel Beránek, Akta komise pro reformu pražské university z r. 1547, Studie o rukopisech 31, 1995-1996, s. 45-67; TÝž, Akta filozofické fakulty Pražské univerzity 1641-1655, 1664-1670, Praha 1997; TÝž, Mistři, bakaláři a studenti pražské filozofické fakulty 1640-1654, Praha 1998; TY̌ž, Zprávy o bojich se Švédy po dobytí Malé Strany a Pražského hradu roku 1648 v diáři koleje sv. Klimenta, Praha 2002; a rozsáhlý soubor edic ve sborníku jeho prací: Karel BERÁNEK, Zkušebni a promočni rády pražské artistické fakulty v 16. a počátkem 17. století, Příspěvky k dějinám vzdělanosti v českých zemích 3, 2000, s. 19-50; TY̌ž, Statuta pražské filozofické fakulty z roku 1614, tamtéž, s. 51-60; TÝž, Návrhy statut pražské univerzity z let 1654-1655, tamtéž, s. 61-97; TY̌ž, Statuta pražské lékařské fakulty z konce 17. století, tamtéž, s. 99-172.

47 Z jejich studií zejména Mlada Holá - Martin Holý, Správa a každodenní provoz koleje Českého národa na pražské univerzitě v 16. století, Paginae Historiae 22/2, 2014, s. 115-123; Mlada HolÁ, Alumni koleje Českého národa na pražské univerzitě v letech 1542-1611, AUC-HUCP 53/2, 2013, s. 41-80; TÁž, Studentské koleje pražské univerzity v pozdním středověku a raném novověku. Dějiny - správa - úřední písemnosti (do roku 1622), Praha 2017; Mlada Holá - Martin Holý (Hg.), Das Studentenkolleg der Böhmischen Nation der Prager Universität. Edition der Rechnungen aus den Jahren 1541-1611, Berlin 2019.

48 A. P. Neuräutter, Promotio doctoralis A. I. Schamsky, faksimilový reprint připravili Josef Petráñ - Blanka ŠACHOvÁ - Karel BeráneK, Praha 2001; Jan Jessenius z JASEné: Průběh pitvy jím slavnostně provedené v Praze L. P. MDC, k niž byl přčcleněn traktát o kostech, přeložila a k vydání připravila Bohdana DivišovÁ, Praha 2004.

49 Tomáš NeJeschlebA, Jan Jessenius v kontextu renesančni filosofie, Praha 2008.

50 Vavřinec Benedikt z NudožER, Grammaticae Bohemicae ad leges naturalis methodi conformatae, et notis numerisque illustratae ac distinctae, libri duo, ed. Nancy Susan Sмгтн, Ostrava 1999.

51 Martin Svatoš, Testimonia de vita Joannis Marci Marci (Svédectví o životě a smrti Jana Marka Marci), AUC-HUCP 43/1-2, 2003, s. 51-79; Richard MАŠEK, Elogium Patris Roderici de Arriaga, in: TÝž (Hrsg.), Roderigo de Arriaga (†1667), Philosoph und Theologe. Prag 25.-28. Juni 1996, Praha 1998, s. 19-39.

52 Jindřich KvĚT - Daniela TINKová (edd.), Jan Theobald Held, Fakta a poznámky k mému budoucímu nekrologu, I, Vzpomínky pražského lékaře na léta 1770-1799, Praha 2017 (Pamět', sv. 90).

53 Ve vztahu k pražské univerzitě Marek ĎurČANSKÝ, Česká města a jejich správa za třicetileté války. Zemský a lokálni kontext, Praha 2013, s. 121-123.

54 Josef HejNIC - Jan MARTíneK, Rukovět humanistického básnictví, VI, Dodatky A-Ž, Praha 2012. 
Klíčovou otázku pro systematické vydávání pramenů představuje institucionální a personální zajištění. Nechceme nijak bagatelizovat sílu a význam individuálních editorských a badatelských zájmů - dílo Františka Šmahela a Karla Beránka ostatně ukazuje, že pozoruhodných výsledků lze dosáhnout i za komplikovaných podmínek. V dlouhodobém horizontu je ale institucionální zakotvení edičních projektů nezbytné. Z porovnání situace středoevropských univerzit to plyne zcela jasně: v Praze by měl být takovým ohniskem z řady důvodů ÚDAUK, ve Vídni je základem dlouhodobá spolupráce univerzitního archivu s Institutem pro rakouský dějezpyt, mezi jehož publikacemi mají edice k dějinám vídeňské univerzity vyhrazeny svou vlastní řadu. ${ }^{55}$ Do organizační struktury krakovského univerzitního archivu přibylo v r. 2007 oddělení pro výzkum dějin Jagellonské univerzity, jehož hlavním úkolem je vedle samotného výzkumu také vydávání pramenů. Univerzitní archiv v Lipsku, jak se zdá, soustředil své síly v posledních dvou desetiletích hlavně k novověkým dějinám a zároveň s realizací velkého digitalizačního projektu zaměřeného na studenty v 19. století vydal v podobě klasické edice také související matriky.

Nemůžeme alespoň letmo nezmínit roli univerzitních jubileí, protože jsou určitým katalyzátorem zájmu o dějiny vysokých škol a při té prŕíležitosti také ediční činnosti. Při dobrém načasování je tak možné dosáhnout na finanční prostředky, které by jinak byly nedostupné, př́padně začít dlouhodobý projekt, jemuž by za jiných podmínek nebyla přisuzována taková váha. Dosavadní jubilea svědčí ale také o tom, že v minulosti zůstalo leckdy u záměrů (Praha 1948, Krakov 1964). I tady ale představovaly nerealizované plány po letech určitý odrazový můstek pro další generaci univerzitních archivářủ a historiků. ${ }^{56}$

Podívejme se nyní, jak úspěšné byly ve své ediční činnosti badatelé u dalších středoevropských univerzit.

\section{Krakov}

Krakovská univerzita má oproti pražské ve svém vývoji mnohem méně diskontinuit, její institucionální tradice je plynulejší. To je vidět i na tamní kultuře akademické paměti a zájmu o vlastní minulost ${ }^{57}$ - řada starších pramenů zvláště biografického charakteru byla vydána již v době raného novověku, ve 2. polovině 18 . století byl v souvislosti s osvícenskými reformami školství zpracován a vytištěn výběrový univerzitní diplomatár̆, v 19. století potom množství pramenů včetně matrik 15.-18. století. Podobně jako v př́padě našeho liber decanorum byla pro nejstarší dějiny krakovské univerzity dlouho používána edice nejstarší „knihy promocí“ filozofické fakulty editovaná ředitelem univerzitní knihovny Józefem Muczkowským již v polovině 19. století. Údaje pro 15. století byly nedávno nikoli bez souvislosti s kulatým jubileem 600 let jagellonského znovuzaložení krakovské univerzity - podrobeny revizi a vydány ve vzorové edici Antoniho Gąsiorowského a jeho

55 Publikationen des Instituts für Österreichische Geschichtsforschung; pro univerzitní prameny existuje specializovaná řada Quellen zur Geschichte der Universität Wien.

56 Pieter Dhondt (ed.), University Jubilees and University History Writing. A Challenging Relationship, (Scientific and Learned Cultures and Their Institutions, Vol. 13), London - Boston 2014 (rec. Petr SvobodnÝ, AUC-HUCP 55/2, 2015, s. 165-168); srv. Adam Horký, Dějiny ve vlastní režii. Př́běh dějin Karlovy univerzity v proménách 20. století, AUC-HUCP 55/2, 2015, s. 17-80.

57 Nejnověji Maciej ZdANEK, Uniwersytet Krakowski wobec własnej przeszłości w XV-XVI wieku, Kraków 2017. 
spolupracovníků. ${ }^{58}$ Srovnání starší a nové edice ukazuje, v čem se mohou lišit moderní kritická edice a na svou dobu velmi kvalitní edice z první poloviny 19. století - vedle ortografie jsou to zejména samovolné zásahy editora do textu, vynechání údajů považovaných za nedůležité (napřr. marginální př́íisy a údaje o platbách promovaných absolventů), stejně jako naprosté nerozlišování jednotlivých vrstev textu vznikajícího činností řady písařských rukou v průběhu mnoha desetiletí. Na druhou stranu ale srovnání také přináší zásadní zjištění, že údaje starší edice, jež byla ve vědeckém oběhu po jeden a půl století, jsou ve svém jádru korektní (z bezmála pěti tisíc osob bylo nově doplněno pouhých pět), včetně převážně správného čtení a identifikace míst původu. ${ }^{59}$ Intenzivní využití starší edice několika generacemi badatelů vedlo současné editory $\mathrm{k}$ tomu, že do textu umístili kromě odkazů na př́slušné stránky editovaného rukopisu také odkazy na Muczkowského edici.

Kromě toho byly stejným editorem a jeho spolupracovníky zpř́stupněny také nejstarší svazky krakovských matrik s údaji o bezmála 30.000 osob. ${ }^{60}$ Moderní kritická edice je dovedena až do roku 1551, kam podle názorů editorů sahaly jejich „,kompetencje mediewistów“ - vydávání dalších svazků výslovně přenechávají někomu jinému. ${ }^{61}$

Pro raný novověk je $\mathrm{v}$ př́ípadě krakovské univerzity situace obdobná jako v př́padě Prahy $-\mathrm{s}$ výjimkou vydání tzv. liber beneficiorum et benefactorum zahrnující údaje o univerzitních nadacích od počátků do 18 . století nebyly rozsáhlejší edice pramenů úřední povahy realizovány, jsou ale v plánech na nejbližší léta. ${ }^{62}$ Jistou výjimku představuje ediční př́loha v práci M. Bastera o Starnigelově studentské koleji otevřené v r. $1647 .{ }^{63}$

Krakovští univerzitní archiváři se v posledních desetiletích věnovali na rozdíl od dosud uváděných editorů přednostně novověku: před několika lety byla ukončena práce na databázi studentů z let 1850-1918, jejiž hlavní výsledky jsou veřejnosti dostupné v osmi objemných tištěných svazcích. ${ }^{64}$ Od roku 2013 běží obdobný pětiletý projekt pod názvem Corpus academicum Cracoviense. Elektroniczna baza studentów i profesorów Uniwersytetu Krakowskiego w okresie staropolskim 1364-1780, který má zahrnout studenty a profesory

58 Antoni GĄsionowsKi (ed.), Księga promocji wydziatu sztuk Uniwersytetu Krakowskiego z XV wieku, Kraków 2000 (promoce z let 1402-1500, předcházejí statuta 1406 a seznam mistrů 1408); srv. Antoni GĄSIOROWSKI Tomasz JureK - Izabela SkiersKa (edd.), Najstarsza księga promocji Wydzialu Sztuk Uniwersytetu Krakowskiego z lat 1402-1541, s latinským patitulem, Warszawa 2011, s. XXXVII, 1-188 (faksimile), 189-419 (edice a rejstříky), k tomu rec. Ivan HLAVÁČEK, AUC-HUCP 51/2, 2011, s. 116-117. Pro kontext a situaci raně novověkých matrik krakovské univerzity, hlavně v souvislosti s obdobím 1642-1720, pro které matriky scházejí, srv. Marian Cнаснал, Metryki studenckie i spis promowanych Uniwersytetu Krakowskiego od XV do XVIII wieku: przegląd edycji i postulaty, in: Adam Perłakowski (ed.), Edytorstwo źródeł: różne drogi - wspólny cel, Kraków 2017, s. 49-67.

59 A. GĄSIOROWSKI (ed.), Księga promocji wydziału sztuk, s. VII.

60 Antoni GĄSIOROWSKI - Tomasz JUREK - Izabela SKIERSKA, przy współpracy Ryszarda GrzesiKa (edd.), Metryka Uniwersytetu Krakowskiego z lat 1400-1508, I-II, Kraków 2004; Tíž (edd.), Metryka czyli album Uniwersytetu Krakowskiego z lat 1509-1551, Warszawa 2010 (též CD-ROM rukopisu); srv. rec. I. HLAvÁčKA v AUC-HUCP 44/1-2, 2004, s. 229-231; tamtéž 50/1, 2010, s. 269-270.

61 A. Gąsiorowski - T. JureK - I. SkiersKa (edd.), Metryka czyli album, s. XLIII.

62 Přehled dosavadních edičních počinů a plánů podává Maciej ZDANEK, Edycje ksiag urzędowych Uniwersytetu Krakowskiego - dzieło na nowo podjęte, in: Krzysztof Kopiński - Wojciech Mrozowicz - Janusz Tandecki (edd.), Editiones sine fine, I, Toruń 2017, s. 67-89.

63 Marcin BAster, Bursa Starnigielska. Z dziejów kolegiów Uniwersytetu Krakowskiego w XVII i XVIII wieku, Kraków 2015, edice na s. 159-396.

64 Krzysztof Stорка et al. (edd.), Corpus studiosorum Universitatis Iagiellonicae 1850-1918, I-VIII, Kraków 1999-2015. Další biografické publikace pomíjíme. 
v počtu přibližně 12.000 osob. Jako pramenný základ jsou využívány prameny vydané i nevydané, biografické slovníky atd. ${ }^{65}$

Kromě klasických edic vyšla zajímavá studie věnovaná autografům krakovských mistrů. ${ }^{66}$ Shodně s českou situací je evidentní také zájem o významné mistry-teology, včetně těch, kteří prošli i Prahou. ${ }^{67}$

\section{Vídeň}

Vídeňská univerzita měla větší štěstí na dochování pramenů než její starší sestra v Praze. $\mathrm{K}$ dispozici jsou matriky různého typu i akta jednotlivých fakult. ${ }^{68}$ Ve starší době se ediční činnost soustředila na rektorské matriky, ${ }^{69}$ novější aktivity přecházejí jednak na mladší období ${ }^{70}$ a jednak na matriky dílčí - napřr. právnické fakulty. ${ }^{71}$ Zpřístupňování je provázeno analytickými studiemi ${ }^{72}$ a využitím virtuálního prostoru. Jak matriky 18 . století, tak středověké úřední knihy - právnická matrika, akta lékařské fakulty, rejstřík artistů, a samozřejmě i zakládací listiny atd. jsou dostupné na internetu. ${ }^{73}$

Dnešní vídeňská univerzita projevuje zvýšenou snahu o sebeprezentaci prostřednictvím připomenutí vlastních dějin, a to např. i na webu, kde jsou popularizována některá témata

65 Marcin Baster, Corpus Academicum Cracoviense. Database of Students and Professors of the University of Krakow (1364-1780), in: Krzysztof Ożóg - Maciej Zdanek (Hgg.), Universitätsstudium und Gesellschaft in Mitteleuropa vom 15. bis zum 18. Jahrhundert, Kraków 2017, s. 265-276.

66 Dagmara WóJCIK-ZEGA, Autografy piętnastowiecznych profesorów krakowskich w rękopisie Archiwum Uniwersytetu Jagiellońskiego 63, Studia źródłoznawcze. Commentationes, 53, 2015, s. 71-109 (s katalogem ukázek písma a biogramy profesorů).

67 Srv. zde pozn. 32-35. Citace biografických studií i dalších edic uvádí Krzysztof OżóG, The Role of Poland in the Intellectual Development of Europe in the Middle Ages, Kraków 2009.

68 Přehled pramenů je k dispozici na webové adrese: https://bibliothek.univie.ac.at/archiv/quellen_zur_geschichte_der_universitaet_wien.html < ověřeno 9.9. 2018>. Dochovala se kniha statut; akta fakult artistické, lékařské a teologické; celouniverzitní kopiář; matrika národa uherského, matriky právnické, a konečně matriky celouniverzitní od 1377. Charakteristiky pramenů pro vídeňskou univerzitu a výčet hlavních typů systematicky podal Kurt Mühlberger, Absolventen der Universität Wien in der Frühen Neuzeit. Perspektiven, Tendenzen, Quellen und offene Fragen, in: Rainer A. Müller (Hg.), Promotionen und Promotionswesen an deutschen Hochschulen der Frühmoderne (Abhandlungen zum Studenten- und Hochschulwesen 10), Köln 2001, s. 169-186, zejména s. 176 a 179-184; srv. také Paul UiBLeIn, Zur Quellenlage der Geschichte der Wiener Universität im Mittelalter, Österreich in Geschichte und Literatur 7, 1963, s. 161-166.

69 K počátkům ediční činnosti srovnej Kurt MüHLberger, Die Matrikel der Universität Wien, in: Grete Klingenstein - Fritz Fellner - Hans Peter Hye (Hgg.), Umgang mit Quellen heute. Zur Problematik neuzeitlicher Quelleneditionen vom 16. Jahrhundert bis zur Gegenwart (= Fontes rerum Austriacarum, 2. Abteilung, Diplomataria et acta 92), Wien 2003, s. 80-88. Ediční řada byla zahájena v 50. letech, pokračovala v letech 70. a posléze došlo k přerušení: Die Matrikel der Universität Wien, I-V, Wien 1956-1975 (více editorů).

70 Vydávání bylo oživeno v 90. letech a dodnes dospělo k r. 1778: Kurt MüHLBERgER (Hg.), Die Matrikel der Universität Wien, VI, 1689/90-1714/15; VII, 1715/16-1745/46; VIII, 1746/47-1777/78; vyšlo 1993, 2011, 2014; k zatím poslednímu 8. svazku viz: http://bibliothek.univie.ac.at/archiv/uaw_publikation_-_die_mat.html <ověřeno 9. 9. 2018>.

71 Kurt Mühlberger (Hg.), Die Matrikel der Wiener Rechtswissenschaftlichen Fakultät - Matricula Facultatis Juristarum Studii Wiennensis, I, 1402-1442, Wien 2011; Thomas MAISEL - Johannes SEIDL, Die Matrikel der Wiener Rechtswissenschaftlichen Fakultät, II, 1442-1557, Wien 2016 (Publikationen des Instituts für Österreichische Geschichtsforschung), také jako e-book: http://www.boehlau-verlag.com/download/164627/978-3-205-20255-4_1_OpenAccess.pdf < ověřeno 9. 9. 2018>.

72 Viz Jiří PEŠEK, Videňská universita středověku a raného novověku v zrcadle novějšich výzkumů, AUC-HUCP 51/2, 2011, s. 132-137.

$73 \mathrm{http}: / /$ bibliothek.univie.ac.at/archiv/digitales_archiv.html < ověřeno 9. 9. 2018>. 
za použití dobových dokumentů, vč. jejich fulltextů a bibliografie. ${ }^{74}$ Především ale připravuje rozsáhlou digitalizaci svých archiválií, kterou představil na archivní konferenci ve Vídni v roce 2017 Thomas Maisel. ${ }^{75}$

Vedle rozsáhlejších edičních podniků se objevila také drobnější práce věnovaná druhé zakládací listině vídeňské Rudolfiny z roku 1384. Kromě analýzy dokumentu nabízí publikace moderní edici jeho původního textu i dobového německého překladu. Opatření listiny téměř třemi desítkami pečetí vede k zamyšlení nad snahou o ukotvení univerzity v tehdejší společnosti a rolí obnoveného zakládacího aktu. ${ }^{76}$

\section{Lipsko}

Také lipská univerzita má dochovány středověké matriky a také zde se začaly vydávat už na sklonku 19. stol. ${ }^{77}$ Po roce 2000 se veškeré úsilí soustředilo na blížící se kulaté jubileum univerzity. ${ }^{78} \mathrm{~V}$ rámci oslav byla vydána řada publikací, z nichž zde musí být zmíněny pětisvazkové dějiny ${ }^{79}$ - velmi dobře koncipovaná syntéza, která rozhodně není jen výroční reprezentační publikací. Dále vyšla edice rektorských řečí, ${ }^{80}$ ale starších dějin se týká jen vydání zakládacích dokumentů. Podobně jako ve Vídni nabízí publikace originální text a překlad 3 listin, poskytuje všechny potřebné údaje o jejich dochování, př́ipomíná okolnosti založení vč. biogramů mistrů, kteří přišli z Prahy, a přináší zajímavý obrazový doprovod. ${ }^{81}$

Také lipský univerzitní archiv nabízí na svých stránkách celou řadu digitalizovaných archiválií (přístup k nim však vyžaduje předběžnou registraci). Již první nahlédnutí

74 http://geschichte.univie.ac.at/de/inhaltsverzeichnis < ověřeno 9. 9. 2018>. Tištěná bibliografie se připravuje: Kurt MüHLBERGER, Bibliographie zur Universitätsgeschichte - in Vorbereitung.

75 Publikováno: Thomas MAISEL, Die digitale Archivnutzung und ihre Herausforderungen für kleinere Archive, in: Jens Blecher - Sabine Happ - Juliane Mikoletzky (Hgg.), Normen und Ethos. Schreiben Archivarinnen und Archivare Geschichte? (Wissenschaftsarchive, Bd. 6), Leipzig 2018, s. 171-174. Odkaz na webové stránky projektu Phaidra: https://phaidra.univie.ac.at/view/o:527682<ověřený přístup 1. 2. 2019>.

76 Christian Lackner, Möglichkeiten und Perspektiven diplomatischer Forschung. Zum Privileg Herzog Albrechts III. für die Universität Wien vom Jahre 1384 (Stabwechsel. Antrittsvorlesungen aus der Historisch-Kulturwissenschaftlichen Fakultät der Universität Wien, Band 4), Wien - Köln - Weimar 2013 (s edicí). K tomu recenze Ivan HLAVÁČEK, AUC-HUCP 53/2, 2013, s. 219-221.

77 Georg Erler (Hg.), Die Matrikel der Universität Leipzig, I-II, Leipzig 1895, reprint Nendeln/Lichtenstein 1976 (v rámci ediční řady Codex diplomaticus Saxoniae, pro leta 1409-1559). Pokračování vydal pod titulem: Týž (Hg.), Die jüngere Matrikel der Universität Leipzig, 1559-1809, als Personen- und Ortsregister bearbeitet und durch Nachträge aus der Promotionsliste ergänzt, Leipzig 1909. Aktuálně vydává ředitel Archivu Lipské univerzity J. Blecher matriky z let 1809-1909: Jens BLECHER - Gerald WIEMERS, Die Matrikel der Universität Leipzig, I, Die Jahre 1809 bis 1832, II, Die Jahre 1832 bis 1863, III, Die Jahre 1863 bis 1876, IV, Die Jahre 1876 bis 1884, V, Die Jahre 1884 bis 1892, VI, 1892 bis 1901, VII, 1901 bis 1909, und Personenregister der Teilbände I bis VII, Weimar 2006-2014. Poslední svazek s rejstř́iky se připravuje.

78 Srv. soubor recenzí v AUC-HUCP 53/2, 2013.

79 (Senatskommision zur Erforschung der Leipziger Universitäts- und Wissenschaftsgeschichte, ed.), Geschichte der Universität Leipzig 1409-2009, Bd. I-V, Leipzig 2009-2010.

80 Franz Häuser (Hg.), Die Leipziger Rektoratsreden 1871-1933, Bd. I-II, Berlin - New York 2009 (edice); Detlef DöRING v čele vědeckého týmu připravuje vydání korespondence Johanna Christopha Gottscheda.

81 Enno BüNZ - Tom GraBER, Die Gründungsdokumente der Universität Leipzig (1409). Edition - Übersetzung Kommentar, Dresden 2010 (Spurensuche. Geschichte und Kultur Sachsens, Bd. 3), s edicí tř́i dokumentů a faksimilí zakládací listiny. Srv. recenzi in AUC-HUCP 53/2, 2013, s. 215-217. 
prozradí, že lipská alma mater je oproti té pražské vybavena již pro středověk větším pramenným bohatstvím. ${ }^{82}$

Na okraj připomeňme, že i další středoevropská univerzita - vratislavská - prezentovala nedávno své fundační dokumenty, leč jedná se o pozdní založení (poté, co se první nepovedlo). ${ }^{83}$ I zde dostává zájemce do ruky edici textu a jeho překlad i fotografie.

\section{Závěr}

Místo závěru si pod dojmem rešerše ke stavu zpřístupňování pramenů ke starším dějinám středoevropských univerzit dovolíme nabídnout několik úvah a tezí.

Především jsme svědky snah o reinterpretaci založení a významných událostí spojených se středověkými počátky univerzit - máme na mysli studie Christiana Lacknera o privilegiu knížete Albrechta III. pro vídeňskou univerzitu (1384), Enno Bünze o zakládacích listinách univerzity v Lipsku (obě publikace včetně edic analyzovaných písemností). K nim je možno přiřadit starší úvahy Františka Šmahela o počátcích pražského vysokého učení nyní nově doplněné studiemi o nečekaně objeveném papežském privilegiu od I. Hlaváčka a J. Hrdiny.

Tato situace samozřejmě nahrává potenciálním pokusům o nové edice již dříve vydaných zásadních pramenů. Nebudeme-li chodit daleko a zůstaneme-li v pražských poměrech, můžeme vzít jako př́klad Liber decanorum. Letitá edice je nyní díky skvělé elektronické knihovně Centra medievistických studií přístupná komukoli, zmiňovaná krakovská edice knihy promocí z 15. století ale může být názornou ukázkou, jak moc by nově pojaté rejstříky mohly využití editovaného rukopisu usnadnit, nehledě na revizi samotného textu.

Zatímco u středověkých pramenů máme co do činění spíše s novým vydáním a novým promýšlením pramenů již plně badatelsky využívaných, raně novověké prameny k dějinám středoevropských univerzit na tom jsou co do zpř́stupnění o poznání hůřre. I tady se ale snahy o zlepšení situace objevují, at' už v oblasti digitalizace nebo kritických edic. To samozřejmě není kvalitativně totéž. Teprve edice s adekvátní úvodní studií, poznámkovým aparátem, rejstř́ky a př́ípadně i překladem starší prameny doopravdy zpřístupní, a to nejen pro historiky v užším slova smyslu, ale také pro specialisty zabývající se dějinami např. různých vědních oborů (o poučených laicích ani nemluvě). ${ }^{84}$

82 http://recherche.archiv.uni-leipzig.de/Archivalien <ověřeno 9. 9. 2018>.

83 Rościsław ŻERelik (ed.), Cztery początki. Dokumenty fundacyjne uniwersytetu wrocławskiego, Wrocław 2002 (jedná se o roky 1505, 1702, 1811, 1945; úvod, foto, edice, překlad).

84 Studie byla zpracována v rámci projektu PROGRES Q23 (Dějiny univerzitní vědy a vzdělanosti). 


\title{
Die Zugänglichkeit von Quellen zur Universitätsgeschichte des vormodernen Mitteleuropa. Ein Rückblick auf die letzten zwei Jahrzehnte und eine Vorschau auf die Zukunft
}

\author{
ZUSAMMENFASSUNG
}

Ausgangspunkt dieser Studie ist der auf dem 8. Historikertag in Hradec Králové 1999 gehaltene Beitrag, in welchem B. Zilynská den Quellenstand zur Geschichte der Bildung und die Zugänglichkeit der Quellen bilanzierte. Der aktuelle Beitrag behandelt vor allem die Editionstätigkeit seit etwa 2000, die die altehrwürdigen Universitäten Mitteleuropas betrifft: Prag, Wien, Krakau und Leipzig. Ein solcher Vergleich ermöglicht ein Nachdenken über die Wege und Richtungen, die die Erforschung der mittelalterlichen und frühneuzeitlichen Universitäten jener Region einschlug, in welcher die Prager Universität nach ihrer Gründung durch Karl IV. dominierte. Berücksichtigt werden sowohl gedruckte als auch in digitalisierter Form zugängliche Texte und Aufzeichnungen. Neben amtlichem Material, in dessen Rahmen in jüngster Zeit die Aufmerksamkeit vor allem den Gründungsakten der einzelnen Universitäten galt, wenden sich die Editoren auch dem literarischen Schaffen der Universitätsmagister zu. Während es sich bei den mittelalterlichen Quellen amtlichen Charakters eher um Neuausgaben und um ein erneutes Überdenken der forscherisch schon voll genutzten Quellen handelt, ist es hinsichtlich der Zugänglichkeit der frühneuzeitlichen Quellen zur Geschichte der mitteleuropäischen Universitäten schon deutlich schlimmer bestellt. Doch gibt es auch hier Bemühungen um eine Verbesserung der Lage, sei es im Bereich der Digitalisierung oder kritischer Quellenausgaben. Die aktuelle Bilanz sollte zur Profilierung des von F. Šmahel vorgeschlagenen Projektes am Institut für Geschichte und Archiv der Karlsuniversität (ÚDAUK) verhelfen, nämlich der Editionsreihe Documenta Historica Universitatis Carolinae Pragensis (DUP), deren erster Band (die Universitätsstatuten) schon publiziert wurde. Der Beitrag berührt auch die Frage, welche Rolle Universitätsjubiläen bei der Konzipierung und Herausgabe von Editionen und historischen Publikationen überhaupt und der Schaffung des Universitätsgedächtnisses sowie des Gesamtkonzepts einer Universitätsgeschichte spielen.

Deutsche Übersetzung Wolf B. Oerter

\author{
Marek Ďurčanský \\ Ústav dějin a archiv Univerzity Karlovy \\ marek.durcansky@ruk.cuni.cz \\ Blanka Zilynská \\ Ústav dějin a archiv Univerzity Karlovy \\ blanka.zilynska@ruk.cuni.cz
}

